University of Wollongong

Research Online

Faculty of Commerce - Papers (Archive)

Faculty of Business and Law

March 2002

\title{
Long- and Short-Run Determinants of the Demand for Money in New Zealand: a Cointegration Analysis
}

Abbas Valadkhani

University of Wollongong, abbas@uow.edu.au

Follow this and additional works at: https://ro.uow.edu.au/commpapers

Part of the Business Commons, and the Social and Behavioral Sciences Commons

\section{Recommended Citation}

Valadkhani, Abbas: Long- and Short-Run Determinants of the Demand for Money in New Zealand: a Cointegration Analysis 2002.

https://ro.uow.edu.au/commpapers/398

Research Online is the open access institutional repository for the University of Wollongong. For further information contact the UOW Library: research-pubs@uow.edu.au 


\title{
Long- and Short-Run Determinants of the Demand for Money in New Zealand: a Cointegration Analysis
}

\author{
Abstract \\ The existence of a stable demand for money is very important for the conduct of monetary policy even in \\ this new era of inflation targeting. It is argued that previous work on the demand for money in New \\ Zealand has been either not very satisfactory in a number of ways or outdated. This paper examines the \\ long-run determinants of the demand for M3 employing the Johansen cointegration technique and \\ quarterly data for the period 1988:1-2002:2. This paper finds, inter alia, that the demand for money is \\ cointegrated with real income, the spread between interest on money and on non-money assets, the \\ expected rate of inflation, and the real effective (trade weighted index) exchange rate.

\section{Keywords} \\ Demand for Money, Money and Interest Rates, Cointegration, New Zealand. \\ Disciplines \\ Business | Social and Behavioral Sciences

\section{Publication Details} \\ This article was originallly published as Valadkhani, A, Long- and Short-Run Determinants of the Demand \\ for Money in New Zealand: a Cointegration Analysis, New Zealand Economic Papers, 36(2), 2002, 235-50.
}




\title{
Long- and Short-Run Determinants of the Demand for Money in New Zealand: a Cointegration Analysis *
}

\begin{abstract}
Abbas Valadkhani

\section{Abstract}

The existence of a stable demand for money is very important for the conduct of monetary policy even in this new era of inflation targeting. It is argued that previous work on the demand for money in New Zealand has been either not very satisfactory in a number of ways or outdated. This paper examines the long-run determinants of the demand for M3 employing the Johansen cointegration technique and quarterly data for the period 1988:12002:2. This paper finds, inter alia, that the demand for money is cointegrated with real income, the spread between interest on money and on non-money assets, the expected rate of inflation, and the real effective (trade weighted index) exchange rate.
\end{abstract}

JEL classification numbers: E41, E52, and C32.

Keywords: Demand for Money, Money and Interest Rates, Cointegration, New Zealand.

\footnotetext{
* * I wish to acknowledge Professor Tim Hazledine, the editor and the two anonymous referees whose constructive comments considerably improved an earlier version of this paper. The usual caveat applies.
} 


\section{Introduction}

The existence of a stable demand for money in the long run is very important in the implementation of monetary policy even in this new era of inflation targeting (Hayo, 1999). New Zealand (NZ) experienced high inflation during the 1970s and the 1980s, reaching a peak of 18.4 per cent per annum in 1980. The Reserve Bank of New Zealand's (RBNZ) approach to monetary policy has undergone significant changes since 1984. After 1984 a large number of exchange controls, reserve ratios and direct controls of the operations of financial institutions were removed from New Zealand's financial system and the exchange rate was also floated. From the late 1970s to early 1980s, based on the assumption of a strong and persistent relationship between inflation and the supply of money, monetary policy was conducted by targeting the annual growth of monetary aggregates. However, from 1986 to 1988 the RBNZ conducted monetary policy through control over the "quantity" of cash made available to settlement banks (rather than its price) with no certain target for inflation (Huxford and Reddell, 1996). In 1989 the RBNZ was given responsibility of curbing inflation in a written contract between the Bank and the Government, called the Policy Targets Agreement (PTA). According to a current PTA, on average inflation should not exceed 0-3 per cent on annual basis. It is important to note that from 1991 to 2002 the rate of inflation (excluding interest and GST) was within the specified range with the only exception being the year 2000 .

By the beginning of 1996, a number of indicators such as the trade-weighted index (TWI) of the exchange rate, the shape of the yield curve (loosely defined as the 90-day/5year yield gap), and monetary aggregates were considered prior to the implementation of monetary policy. In 1997 the RBNZ began publishing the so-called the Monetary Conditions Index (MCI) to convey an important message to the public that both interest rate and the exchange rate are important indicators of monetary policy. The MCI is a 
composite index consisting of both the TWI of the exchange rate and the rate of interest on the 90-day bank bills (RBNZ, 1998). The checklist approach was also unsuccessful and finally discontinued in October 1996 due to the fact that the monetary conditions reached a "corner solution" in relation to the trade-off between interest rates and exchange rates.

As of March 1999, approach taken by the RBNZ to monetary policy has been to set the official cash rate (OCR) or the "price" of cash made available to settlement banks in the money market (Archer, Brookes and Reddell, 1999). Prior to this, the monetary policy was mainly concerned with the "quantity" rather than "price". The OCR is now reviewed every six weeks and the RBNZ uses it as a leverage to lend or borrow as much overnight money as necessary to hold the market interest rate at the desired level. However, the TWI of the exchange rate and the shape of the yield curve are still regarded as important monetary indicators. Therefore, following many other OECD countries, inflation targeting has now become the prime goal of monetary policy in NZ. For a concise discussion of the operation of monetary policy in NZ see (Svensson, 2001).

A number of studies have already been undertaken to investigate the demand for money in NZ. The review of literature on the demand for money in NZ briefly presented below indicates a growing consensus among economists that broad monetary aggregates should still be regarded as key indicators of monetary policy. However, given the specific characteristics of monetary policy arrangements in NZ, due consideration should be given to the choice of factors affecting the demand for money.

Siklos (1995a and 1995b) examines the demand for money in NZ using quarterly data for the period 1981:1-1994-2. Given that he has identified a number of important issues, his findings are summarised below.

First, using the Johansen and Juselius cointegration technique, Siklos finds a unique cointegrating vector linking real M3 to income, the expected rate of inflation and 
the difference between the short-run interest rates in NZ and the US. He argues that because transactions on capital account have been deregulated, the demand for M3 should include this interest rate differential. His results indicate that one cannot reject the null of no cointegrating vector unless the US-NZ interest rate differential is included in the cointegrating vector. Second, he asserts that the most relevant price index for deflating nominal money is the consumer price index but this index should exclude changes in the cost of living associated with interest rates. Third, in his four cointegrating vectors, using various price deflators, he obtains an income elasticity varying from 2 to 6.

Siklos also includes the difference between NZ and the US interest rates directly in the VAR model, implying that this variable is completely endogenous in the system. One should note that macroeconomic variables in NZ (as a small open economy) cannot fully affect the interest rate differential. The present study acknowledges the importance of changes in the US interest rate on the demand for money in NZ and thus this variable is included in the VEC model or equation 3 in Section 2 prior to undertaking the cointegration test.

Giles (1998) argues that the demand for M3 does not exhibit any sign of instability as long as both hidden and recorded outputs are included in the scale variable. On the other hand, Razzak (2001) in his empirical analysis of money in NZ indicates that the correlation between money and real output is stronger than that of between money and inflation. He also asserts that there would be no inflationary pressures if the growth rate of money exceeds the growth rate of nominal GDP. Razzak estimates a Keynesian demand for money function linking real monetary base with real output and various types of interest rates. Following Siklos (1995b), his study concludes that the NZ-US interest rate differential is a very important factor which can capture the openness of the economy. 
While all the estimated income elasticities reported by Siklos exceed two, Razzak estimates the income elasticity to be very close to unity. Razzak's study concludes that the recent instability in the demand for money function can be overcome by incorporating the following important explanatory variables into the money demand equation: changes in asset prices, other interest rates, which are beyond the control of the RBNZ (like 10-year government bonds), and the expected rate of inflation.

de Brouwer, Ng and Subbaraman (1993) and Juselius and Hargreaves (1992) use Australian data and correctly conclude that the number of cointegrating vectors and their stability are very sensitive to the choice of scale variable, e.g. GDP or GNE (gross national expenditure), and the measure of money. Using the Johansen test, de Brouwer, $\mathrm{Ng}$ and Subbaraman (1993) have also examined various measures of money, different interest rates, and scale variables, and concluded that there is evidence of cointegration between money, income and the interest rate, particularly for broad money.

There are also two important studies by Orden and Fisher (1993) and Siklos (1997) that highlight the significant role and impact of financial innovations in the context of NZ. More specifically, Orden and Fisher (1993) investigate the dynamic impacts of financial deregulation in the 1980s on money, prices and output for $\mathrm{NZ}$ and Australia employing a VAR methodology. They use a standard Choleski-type of contemporaneous identifying restrictions imposed on the error correction model to obtain various impulse functions. On the other hand, Siklos and Eckhold (1997) specified two models capturing the behaviour of M3 velocity: a conventional velocity model and an extended velocity model. In the latter model they include a number of proxies for institutional change. Their empirical analysis leads to an important conclusion that institutional changes do matter and they must be incorporated to the velocity equation, particularly in the financial deregulation era. 
The objective of this paper is to update the sample and address the problems and shortcomings associated with the previous work on the demand for money. The structure of the paper is as follows. In Section 2 a theoretical model is postulated which captures the long-run demand for money using the Johansen multivariate cointegration technique. Definitions of the variables, sources of the quarterly data employed as well as the unit-root results using the Augmented Dickey-Fuller (ADF) and the Kwiatskowski-PhillipsSchmidt-Shin (KPSS) tests are presented in Section 3. This section also examines the associated issues with the choice of monetary aggregate and other relevant variables in this study. Section 4 presents the empirical econometric results for the long- and short-run demand for money, as well as policy implications of the study are also discussed in this section. Section 5 provides some concluding remarks.

\section{Theoretical framework}

Conventionally the demand for money in the literature (e.g. Ericsson, 1998, Beyer, 1998, Coenen and Vega 2001, and Felmingham and Zhang, 2001) is specified as a function of real income, a long-run interest rate on substitutable non-money financial assets, a short-run rate of interest on money itself, and the inflation rate.

However, the problem with this specification is that it does not include a measure of exchange rate and a foreign interest rate both of which can capture the general process of financial asset substitution, particularly after the 1980s. Mundell (1963, p.484) conjectured that in addition to the interest rates and the level of real income, the demand for money should be augmented by the exchange rate.

Ewing and Payne (1999) have investigated the incorporation of the exchange rate into the demand for narrow money equation in several countries. They utilise a standard cointegration technique to examine the relevance of the inclusion of the effective 
exchange rate in the money demand function. They suggest that "income and interest rate are sufficient for the formulation of a long-run stable demand for money in Australia, Austria, Finland, Italy, U.K., and U.S. However, for Canada, Germany, and Switzerland, the effective exchange rate should be incorporated" (Ewing and Payne, 1999, p.84).

There are a number of studies that have considered general process of financial asset substitution and justified the use of an exchange rate and a foreign interest rate in the analysis of demand for money in other countries. See, inter alia, Bahmani-Oskooee and Rhee (1994), Traa (1991) and Chowdhury (1995). On this same issue McNown and Wallace (1992) highlight the importance of the exchange rate in the money demand function particularly for the period starting with the floating of the U.S. dollar. Based on their empirical investigation, they argue that a stable long-run demand function for M2 (but not for M1) cannot be obtained without the inclusion of the effective exchange rate. Their important study lends "some support to Ronald I. McKinnon's hypothesis that nonstationarity in the demand for money can be resolved by inclusion of the exchange rate" (McNown and Wallace, 1992, p.107). As can be seen all these studies are clearly in favour of both the currency substitution and capital mobility hypotheses.

Therefore it is very important to include the real effective exchange rate (er) and a measure of the long-term foreign interest rate $(F R)$ in the money demand function. However, FR (say the long-run US Treasury bond yield) is determined outside the Vector Autoregressive (VAR) model formulated in this paper because it is plausible to argue that NZ as a small open economy does not have any influence over $F R$. Therefore, it is assumed that $\triangle F R$ (as a totally exogenous variable) enters the Vector Error Correction (VEC) model but not in the cointegrating vector(s). Thus, the long-run demand for money in this paper is specified as: 
$(m-p)_{t}=\gamma_{0}+\gamma_{1} y_{t}+\gamma_{2}(R L-R S)_{t}+\gamma_{3} \pi_{t}^{e}+\gamma_{4} e r_{t}+w_{t}$

where $m$ is nominal money demanded, $p$ is the price level, $y$ is the real GDP-production as a proxy to capture transactions and precautionary demand for money, $R L$ is the long-run rate of return on assets outside of money, $R S$ is the short-run rate of interest on money itself, $\pi^{e}$ is the expected rate of inflation, and $e r$ is the real effective (TWI) exchange rate. All variables shown in lowercase (i.e. $m, y$, er, and $p$ ) are in logs and the remaining variables (i.e. $R L, R S$ and $\pi^{e}$ ) are in levels. As a result, $\gamma_{1}$ and $\gamma_{4}$ denote the income and exchange rate elasticities of the demand for money, whereas $\gamma_{2}$ and $\gamma_{3}$ are semi-elasticities of (RL-RS) or the interest rate spread, and the inflation rate with respect to money demand, respectively.

The expected sign and magnitude of the coefficient for $y$ is as follows: if $\gamma_{1}=1$, the quantity theory applies; if $\gamma_{1}=0.5$, the Baumol-Tobin inventory-theoretic approach is applicable; and if $\gamma_{1}>1$, money can be considered a luxury. According to Ball (2001), an income elasticity of less than unity has a number of implications for monetary policy. For instance, one may conclude that the Friedman rule is not optimal in this case and the supply of money should grow more sluggishly than output to achieve the goal of price stability (Ball, 2001, p.36). For a detailed discussion of controversy about the quantity theory see Laidler (1991).

It is also expected that $R L$, as a proxy for the yields on outstanding government bonds, has a negative sign, whereas the coefficient for the short-run rate of interest is positively correlated with money demand. Following Felmingham and Zhang (2001), the expected annualised rate of inflation $\pi^{e}=\Delta_{4} p_{t+1}$, where $\Delta_{4} p_{t}=\ln \left(P_{t}\right)-\ln \left(P_{t-4}\right)$, is considered as a proxy to measure the return on holdings of goods, and its coefficient should thus be negative, i.e. $\gamma_{3}<0$, as goods (e.g real estate) are an alternative to money. According to 
Ericsson $(1993,309)$, the exclusion or inclusion of inflation in this equation is an issue of dynamic specification. For a comprehensive discussion of the literature on money demand see also, inter alia, Laidler (1993) and Hoffman and Rasche (2001). Bahmani-Oskooee and Rhee (1994) argue that the expected sign for $\gamma_{4}$ could be positive or negative and this is an empirical issue.

In order to have a valid model for the money demand function, there should be at least one cointegrating vector in the system. The Johansen (1991, 1995) multivariate cointegration technique is used in this paper to test the existence of a long-run equilibrium relationship among the variables specified in equation (1). A brief description of this technique is presented below.

Let us consider the following VAR of order q:

$$
y_{t}=A_{1} y_{t-1}+A_{2} y_{t-2}+\cdots+A_{q} y_{t-q}+B x_{t}+w_{t}
$$

where $y_{t}$ is a $k$-vector of $\mathrm{I}(1)$ variables (e.g. in this study $\mathrm{k}=5$ and the variables are $m-p, y$, $R L-R S, \pi^{e}$ and $\left.e r.\right)$, and $x_{t}$ is a $d$-vector of exogenous variables (e.g. in this study we have only one exogenous variable and that is $\Delta F R$ ), and $w_{t}$ is a vector of white noise residuals. Following Johansen (1991, 1995), equation (2) can also be rewritten as:

$$
\Delta y_{t}=\Pi y_{t-1}+\sum_{i=1}^{q-1} \Gamma_{i} \Delta y_{t-i}+B x_{t}+\varepsilon_{t}
$$

where $\Pi=\sum_{i=1}^{q} A_{i}-I$, and $\Gamma_{i}=-\sum_{j=i+1}^{q} A_{j}$

The rank $(r)$ of $\Pi$ determines the number of cointegrating vectors. If $\Pi$ has a reduced rank (i.e. $r<k$ ), then there exist $k \times r$ matrices $\alpha$ and $\beta$ each with rank $r$, where $\Pi=\alpha \beta^{\prime}$ and $\beta^{\prime} y_{t}$ is stationary. The elements of $\alpha$ represent the adjustment parameters and each column of $\beta$ in the literature is referred to as the cointegrating vector. Thus the important issue is how to determine the number cointegrating vectors (or $r$ ). In this paper both the trace statistics and the maximum eigenvalue statistics will determine $r$. The trace 
statistics test the null hypothesis of $r$ cointegrating relations against the alternative of $k$ cointegrating equations. On the other hand, the maximum eigenvalue statistics test the null of $r$ cointegrating vectors versus the alternative of $r+1$ cointegrating relations. For more details see Johansen (1991, 1995).

An important step before using the Johansen multivariate technique is to determine the time series properties of the data. This is an important issue since the use of non-stationary data in the absence of cointegration can result in spurious regression results. To this end, two unit root tests, i.e the ADF test, and the Kwiatskowski-PhillipsSchmidt-Shin (KPSS) test, have been adopted to examine the stationarity, or otherwise, of the time series data. In this paper the lowest value of the Schwarz Information Criterion (SIC) has been used as a guide to determine the optimal lag length in the ADF regression. These lags augment the ADF regression to ensure that the error term is white noise and free of serial correlation. In addition to the ADF test, a KPSS test has been performed for all the variables. Unlike the ADF test, the KPSS test has the null of stationarity, and the alternative indicates the existence of a unit root. A lag length of four is chosen in the KPSS test for the lag truncation parameter $(l)$ in the testing procedure as autocorrelation is highly likely to be of order 4 in quarterly data.

\section{The Data}

The nominal demand for M3R in NZ exhibited an average growth of 1.6 per cent per quarter from 1988:2 to 2002:2 or 6.5 per cent per annum. What are the major long- and short-run determinants of the demand for money during the last fourteen years? Based on the theoretical framework discussed in Section 2, the objective of this paper is to answer this question. 
Before embarking on our empirical quest, it is important to look at the sources and definitions of the data presented in Table 1. Quarterly time series data employed for the period 1988:1-2002:2 are as follows: nominal M3R $(m)$, the consumer price index $(p)$, real GDP-production or $y,(m-p)$, the rate of return on 10-year government bonds as a proxy for $R L$, the interest rate on 90 -day bank bills as a proxy for RS, $\Delta_{4} p_{t+1}$ as a proxy for the expected annualised inflation rate, the real effective (TWI) exchange rate denoted by $e r$, and the long-run rate of return on Treasury bonds in the US as a proxy for $F R$. Following the literature, $R L, R S, F R$ and the expected rate of inflation are expressed as fractions, whereas the other variables are in logs and thus shown in lowercase. Figure 1 presents the plots of time series data employed in this study for the 1988:1-2002:2 period.

Table 1:

Sources and definitions of the data employed

\begin{tabular}{|c|c|c|}
\hline Source & Variables & Unit \\
\hline Table D4* & $\begin{array}{l}\text { The rate of return on the ten-year government } \\
\text { bonds or } R L\end{array}$ & fraction \\
\hline Table D3* & $\begin{array}{l}\text { The interest rate on the 90-day bank bills or } \\
\qquad R S\end{array}$ & fraction \\
\hline $\mathrm{RBNZ}^{* *}$ & $\begin{array}{l}\text { Real effective (TWI) exchange rate index or } \\
\text { ER and } e r=\ln (\mathrm{ER})\end{array}$ & $1979=100$ \\
\hline Table D4* & The US long-run interest rate or $F R$ & fraction \\
\hline $\mathrm{RBNZ}^{* *}$ & $\mathrm{M} 3 \mathrm{R}=\mathrm{M} 3$ - non-residents transactions & million NZD \\
\hline \multicolumn{3}{|c|}{ Note: Above 5 variables are monthly data but they have been averaged to make them quarterly. } \\
\hline Table C $1^{*}$ & $\begin{array}{l}\text { The consumer price index or P, where } p=\ln (\mathrm{P}) \\
\text { and } \pi^{e}=\Delta_{4} p_{t+1}\end{array}$ & $(1996=100)$ \\
\hline Table F14 & Real GDP-production series or $\mathrm{Y}$ and $y=\ln (\mathrm{Y})$ & $\begin{array}{l}\text { at constant prices } 1995-96 \\
\text { (NZD '000)-sa }\end{array}$ \\
\hline \multicolumn{3}{|c|}{ * ABS (2002), OECD, AusStats online time series database available at http://www.abs.gov.au } \\
\hline \multicolumn{3}{|c|}{${ }^{* *}$ RBNZ (2002), Online time series database available at http://www.rbnz.govt.nz/statistics/monfin/index.html } \\
\hline
\end{tabular}

de Brouwer, Ng and Subbaraman (1993) in their study of the demand for money in Australia point out that compared with other measures of money, the evidence of cointegration is stronger when broad money is modelled as it: a) is less distorted by 
financial deregulation and innovations; and b) has a more reliable relationship with GDP. In this paper M3R (excluding non-residents' transactions from M3), which is the broadest and most relevant measure of money in NZ, is preferred to other narrower measures of money such as monetary base, M1 and M2. It should be noted that an important part of the M3 transactions relates to non-residents and therefore in this study M3R has been chosen as a more relevant measure of money in NZ. Felmingham and Zhang (2001) argue that narrow measures of money can be substantially affected by asset substitution and are also more volatile.

Ericsson (1998) suggests that long-run rates should not be included in the demand equation for M1. However, if a broader definition of money is modelled, it is essential to incorporate longer-term interest rates in the demand for money function so as to capture financial asset substitutions. As mentioned earlier, M3R is the broadest monetary aggregate, and therefore $R L$ is best proxied by a "long-run rate" such as the rate of interest on 10-year government bonds, a security with the longest maturity for which the quarterly time series data are available. The broader the definition of money, the longer rates would be more relevant.

Prior to undertaking an empirical investigation of the sources of demand for M3, it is essential to determine the time series properties of the data. In order to make robust conclusions about stationarity or otherwise of the data, the ADF and the KPSS tests are utilised. The empirical results of the ADF and KPSS tests are summarised in Table 2.According to the results of the ADF and KPSS tests, $m, p$ and $m-p$ are $\mathrm{I}(1)$, indicating that these variables become stationarity after first differencing. All the other variables, i.e $\mathrm{y}, R L, R S, \pi_{t}^{e}$, er and $F R$, are also I(1). It should be noted that according to the KPSS test $F R$ is $\mathrm{I}(1)$, whereas the ADF test supports the view that this variable is $\mathrm{I}(0)$. Using the KPSS test results, it is assumed that $F R$ is I(1). 


\section{Empirical Results and Policy Implications}

Since all the variables in equation (1) are $\mathrm{I}(1)$ and $\Delta F R$ in equation (3) is $\mathrm{I}(0)$, the Johansen $(1991,1995)$ multivariate cointegration technique can now be used to test the existence of a long-run equilibrium relationship for M3. Following Coenen and Vega (2001), an unrestricted intercept and a linear trend in the variables but not in the cointegrating vectors enter the system. The first important step in this test is to determine the optimal lag length (q) in equation (3). Because the sample size is relatively small, one needs to use parsimonious lag selection criteria. Allowing for an upper band of 4 lags, two lag selection criteria of the HQ (Hannan-Quinn information criterion) and the SIC have been employed to determine q. Based on these criteria (not reported here but available from the author upon request), the optimal lag length is $q=1$. It should be noted that Siklos (1995b) in his empirical analysis of the demand for money for NZ (using the same number of observations or 14 years of quarterly data) has also chosen the SIC as a more parsimonious lag selection criterion. Various diagnostic tests indicate that the system of equations with one lag is well behaved. Table 3 reports the results of the Johansen multivariate cointegration test on the demand for M3R as formulated in equation (1). According to both the trace and max-eigenvalue tests there is robust evidence of one cointegrating vector at the 1 per cent level.

From Table 4 the long-run parameters are seen to be of consistent sign and orders of magnitude and highly significant. It should be noted that the eigenvalue associated with the first vector $(0.57)$ is considerably higher than those corresponding to the other vectors, thereby validating that there exists a unique cointegrating vector in the system. 
Table 2:

KPSS and ADF test results 1988:2-2002:2

\begin{tabular}{|c|c|c|c|c|}
\hline \multirow[b]{2}{*}{ Variable } & \multirow{2}{*}{$\begin{array}{c}C \text { (constant) and } \\
T \text { (trend) in the } \\
\text { equation }\end{array}$} & \multicolumn{2}{|c|}{ ADF test } & \multirow{2}{*}{$\begin{array}{c}\text { KPSS } \\
\text { Statistics }\end{array}$} \\
\hline & & $\begin{array}{c}\text { ADF } \\
\text { statistics }\end{array}$ & $\begin{array}{l}\text { Optimum } \\
\text { lag }\end{array}$ & \\
\hline$m$ & $C \& T$ & -1.54 & 0 & $0.179^{*}$ \\
\hline$\Delta m$ & C & $-8.56^{*}$ & 0 & 0.129 \\
\hline$p$ & $C \& T$ & -2.68 & 1 & $0.180^{*}$ \\
\hline$\Delta p$ & $C$ & $-4.81^{*}$ & 0 & 0.327 \\
\hline$(m-p)$ & $C \& T$ & -2.38 & 0 & $0.149^{*}$ \\
\hline$\Delta(m-p)$ & $C$ & $-7.84^{*}$ & 0 & 0.218 \\
\hline$y$ & $C \& T$ & -2.18 & 0 & $0.152^{*}$ \\
\hline$\Delta y$ & $C$ & $-7.04^{*}$ & 0 & 0.250 \\
\hline$R L$ & $C \& T$ & -1.54 & 2 & $0.221^{*}$ \\
\hline$\Delta R L$ & $C$ & $-5.97^{*}$ & 1 & 0.234 \\
\hline$R S$ & $C \& T$ & -2.52 & 1 & $0.154^{*}$ \\
\hline$\Delta R S$ & $C$ & $-4.69^{*}$ & 0 & 0.178 \\
\hline$e r$ & $C \& T$ & -2.10 & 1 & $0.157^{*}$ \\
\hline$\Delta e r$ & $C$ & $-4.69^{*}$ & 0 & 0.106 \\
\hline$F R$ & $C \& T$ & $-3.67^{*}$ & 1 & $0.111^{* *}$ \\
\hline$\Delta F R$ & C & $-6.46^{*}$ & 0 & 0.038 \\
\hline
\end{tabular}

and ${ }^{* *}$ indicate that, based on the MacKinnon, and the KwiatkowskiPhillips-Schmidt-Shin critical values, the corresponding null hypothesis is rejected at the 5 and $10 \%$ significance levels, respectively.

Table 3:

Johansen test for cointegration

\begin{tabular}{cccccc}
\hline $\begin{array}{c}\text { Hypothesized } \\
\text { No. of CE(s) }\end{array}$ & Eigenvalue & $\begin{array}{c}\text { Trace } \\
\text { statistic }\end{array}$ & $\begin{array}{c}1 \% \text { critical } \\
\text { value }\end{array}$ & $\begin{array}{c}\text { Max. } \\
\text { Eigenvalue } \\
\text { statistic }\end{array}$ & $\begin{array}{c}1 \% \text { critical } \\
\text { value }\end{array}$ \\
\hline None & 0.567 & $92.6^{*}$ & 76.1 & $46.0^{*}$ & 38.8 \\
At most 1 & 0.447 & 46.6 & 54.5 & 32.2 & 32.2 \\
At most 2 & 0.146 & 13.9 & 35.7 & 8.8 & 25.5 \\
At most 3 & 0.092 & 5.3 & 20.0 & 5.3 & 18.6 \\
At most 4 & 0.000 & 0.00 & 6.7 & 0.002 & 6.7 \\
\hline
\end{tabular}

* indicates that the corresponding null hypothesis is rejected at $1 \%$ significance level.

As can be seen from the results obtained from the cointegrating vector in Table 4, the long-run demand for $(m-p)$ is negatively related to the interest rate spread (defined as $R L-R S)$, the expected inflation rate and the real effective exchange rate. The discussion of these long-run coefficients is presented later in this section. 
Table 4:

Standardized cointegrating vector and the corresponding adjustment coefficients

\begin{tabular}{cccccc}
\hline $\begin{array}{c}\text { Cointegrating } \\
\text { vector }\end{array}$ & $\begin{array}{c}\beta \\
\text { Coefficients }\end{array}$ & $t$ ratio & VEC equation & $\begin{array}{c}\alpha \\
\text { Coefficients }\end{array}$ & $t$ ratio \\
\hline$(m-p)_{t-1}$ & 1 & - & $\Delta(m-p)_{t}$ & -0.213 & -3.6 \\
$y_{t-1}$ & -1.47 & -37.7 & $\Delta y_{t}$ & 0.051 & 0.88 \\
$R L_{t-1}-R S_{t-1}$ & 4.03 & 7.1 & $\Delta(R L-R L)_{t}$ & -0.105 & -3.8 \\
$\pi_{t-1}^{e}$ & 4.08 & 13.7 & $\Delta \pi_{t}^{e}$ & -0.014 & -0.36 \\
$e r_{t-1}$ & 0.208 & 3.3 & $\Delta e r_{t}$ & 0.151 & 1.23 \\
Constant & 4.85 & - & & & \\
\hline
\end{tabular}

Table 4 also shows the estimated adjusted coefficients ( $\alpha$ s), which can be used to test for weak exogeneity. The adjustment coefficients contain weights with which cointegrating vector(s) enter short-run dynamics. Given that this study finds only one cointegrating vector, Table 4 presents the first column of the $\alpha$ matrix. These coefficients measure the speed of the short-run response to disequilibrium occurring in the system. Before proceeding any further, it is essential to test for weak exogeneity of the four variables on the right hand side of equation (1) with respect to $(m-p)$. The Johansen method enables analysts to test for weak exogeneity by imposing zero restrictions on the weighting coefficients of $\alpha_{\mathrm{y}}, \alpha_{\mathrm{RL}-\mathrm{RS}}, \alpha_{\pi}$, and $\alpha_{\mathrm{er}}$. One should note that the $e c$ term is significant and correctly signed $(-0.213)$ in the VEC equation for $(m-p)$.

Table 5, inter alia, presents the test results for separate and joint restrictions on the weighting coefficients. As can be seen from the separate and joint zero restrictions on the corresponding $\alpha \mathrm{s}$, the ec term is highly significant for in the VECs or the shortrun dynamic equations for $\Delta(m-p)$ and $\Delta(R L-R S)$, but not for $\Delta y, \Delta \pi^{e}$ and $\Delta e r$. Therefore, these results indicate that while income, inflation and the exchange rate are weakly exogenous with respect to real money balances, the interest rate spread is not. 
Table 5:

Testing for restrictions on the $\alpha s$ and the $\beta s$

\begin{tabular}{ccc}
\hline The null hypothesis & Statistic & Probability \\
\hline$\alpha_{m-p}=0$ & $\chi^{2}(1)=10.1^{*}$ & 0.001 \\
$\alpha_{y}=0$ & $\chi^{2}(1)=0.78$ & 0.380 \\
$\alpha_{R L-R S}=0$ & $\chi^{2}(1)=5.9^{*}$ & 0.010 \\
$\alpha_{\pi e}=0$ & $\chi^{2}(1)=0.07$ & 0.790 \\
$\alpha_{e r}=0$ & $\chi^{2}(1)=1.51$ & 0.220 \\
$\gamma_{l}=1$ & $\chi^{2}(1)=6.5^{*}$ & 0.011 \\
$\alpha_{y}=\alpha_{R L-R S}=\alpha_{\pi e}=\alpha_{e r}=0$ & $\chi^{2}(4)=22.9^{*}$ & 0.000 \\
$\alpha_{y}=\alpha_{\pi e}=\alpha_{e r}=0$ & $\chi^{2}(3)=2.30$ & 0.518 \\
indicates that the relevant null is rejected at 1\% level.
\end{tabular}

Let us now test the null of $\gamma_{1}=1$. As seen from Table 5, the estimated long-run income elasticity (1.47) seems reasonably above unity which is in stark contrast with the quantity theory of money and other studies for developed countries, e.g. Beyer (1998) in his study of M3 in Germany, Coenen and Vega (2001) in their recent study of M3 in the Euro area, and Ericsson (1998) in his analysis of the narrow demand for money in the UK. Nevertheless, one needs to test formally the $\gamma_{1}=1$ assumption on the cointegrating vector. Table 5 also presents the likelihood ratio (LR) test result for this restriction. Given that $\chi^{2}(1)=6.5$ [probability $=0.011$ ], one can easily reject the null of $\gamma_{1}=1$ at 1 per cent level. Consistent with the results obtained by Razzak (2001), Siklos and Eckhold (1997) and Siklos (1995a and 1995b), it can be concluded that the quantity theory is not applicable in the context of NZ.

Attention is now directed on the discussion of the long-run coefficients. The estimated cointegrating vector is presented below.

$$
(m-p)_{t}=1.47 y_{t}-4.03(R L-R S)_{t}-4.08 \pi_{t}^{e}-0.21 e r_{t}-4.9
$$

As seen from equation (4), one per cent increase in real income stimulates the real demand for M3R by almost 1.5 per cent. The intercept coefficient in equation (4) captures things like technological change in financial instruments and increases in 
wealth etc. Given that the estimated coefficients of -4.03 and 4.08 are the semielasticities for $R L-R S$ and $\pi^{e}$, respectively, one can argue that the impact of an increase in the interest rate spread on real money balances is almost the same as that of the expected inflation rate. As mentioned earlier, the interest rate spread is not weakly exogenous with respect to $(m-p)$. This simply means that to some extent a change in real money balances can also affect $R L-R S$. However, this does not imply that the RBNZ can fully control the interest rate spread. Consistent with theoretical postulates discussed in Section 2, the cointegrating vector clearly shows that an increase in the expected rate of inflation or a depreciation of NZ dollar can encourages agents to diversify their portfolios in the economy by acquiring real domestic assets and/or foreign financial assets.

The magnitude of the estimated coefficient for $e c$ (the error correction term) in the VEC model (reported later in this section, Table 6) indicates that the lagged excess money will reduce holdings of money by 31 per cent in each quarter. It is interesting to note that Siklos and Eckhold (1997) in their quest for modeling income velocity in NZ also find a similar fast adjustment process (i.e. 33\%). Therefore, every quarter 31 per cent of the divergence between the short-run demand for real balances from its longterm path is eliminated.

From the significant adjustment coefficient for $\Delta(R L-R S)$ reported in Table 4 (i.e. $\left.\alpha_{R L-R S}=-0.105\right)$, it is clear that the lagged excess real money balances, i.e. $m_{t-1}^{d}>m_{t-1}^{s}$ or a temporary shortage of money in the economy, ceteris paribus, can be eliminated quickly. In other words, every quarter 10.5 per cent of the divergence between the shortrun interest rate spread from its long-term path is eliminated. Therefore, if the spread temporarily diverges from its long-run path, in less than 10 quarters the created disequilibrium will be removed. 
Using the resulting residuals (the $e c$ term) from the long-run relationship in equation (4), one can estimate a VEC model which captures the short-run dynamics of the demand for money. That is:

$$
\begin{aligned}
\Delta(m-p)_{t}= & \varphi_{0}+\sum_{i=0}^{q_{1}} \varphi_{1 i} \Delta y_{t-i}+\sum_{i=0}^{q_{2}} \varphi_{2 i} \Delta(R L-R S)_{t-i}+\sum_{i=0}^{q_{3}} \varphi_{2 i} \Delta \pi_{t-i}^{e}+ \\
& \sum_{i=0}^{q_{4}} \varphi_{4 i} \Delta e r_{t-i}+\sum_{i=0}^{q_{5}} \varphi_{4 i} \Delta F R_{t-i}+\sum_{i=1}^{q_{6}} \varphi_{4 i} \Delta(m-p)_{t-i}+\theta E C_{t-1}+v_{t}
\end{aligned}
$$

where $\varphi_{i j}$ are the estimated short-term coefficients; $\theta$ is the feedback effect or the speed of adjustment, whereby short-term dynamics converge to the long-term equilibrium path; and the lagged dependent variables are added to ensure that $v_{t}$ (or the residual) is white noise.

Starting with a maximum lag of four for $\mathrm{q}_{1}$ to $\mathrm{q}_{6}$, the general-to-specific methodology is now used to omit the insignificant variables in equation (5) on the basis of a battery of maximum likelihood tests. Using $\mathrm{I}(0)$ variables in the estimating procedure, joint zero restrictions are imposed on explanatory variables in the general model or equation (5) to obtain the most parsimonious and robust estimators. The empirical results for the parsimonious model capturing short-run dynamics for money demand are presented in Table 6. All the estimated coefficients are statistically significant at least at the 5 per cent level and have the expected theoretical signs. This equation also performs extremely well in terms of goodness-of-fit statistics and it passes each and every diagnostic test.

The estimated coefficients have been correctly signed, with the change in the rate of return on non-financial assets (as proxied by the expected inflation rate) and the interest rate spread having current negative semi-elasticities of -0.368 and -0.717 , respectively. Note also that the short-run income elasticity is well below unity (0.27). This "suggests not only the possibility of economies of scale in the management of M3 
holdings but it also signals the potential for a diminution in the information content of M3 as an indicator of monetary policy" (Siklos and Eckold, 1997, p.48). Furthermore, the feedback coefficient for the $e c$ term is highly significant, validating the significance of the cointegration relationship in the short-run model for money demand. The magnitude of the estimated coefficient for $e c$ indicates that the lagged excess money will reduce holdings of money by almost 32 per cent in each quarter. Thus, in the short run it can be stated that income, the interest rate spread, the expected inflation, and the real exchange rate are the main driving forces of changes in money demand.

As mentioned earlier, $\gamma_{4}$ could be positive or negative and this is an empirical issue. Tables 4 and 6 show that the estimated elasticity for er is negative in the long run but positive in the short run. This implies that the depreciation of NZ dollar can temporarily increase the demand for money in the short run but if the currency depreciation persists over a longer period, agents will substitute other currencies for the NZ dollar in their financial portfolio.

One problem associated with the analysis of the demand for money is nonconstancy or instability of estimated coefficients, which can create economic and econometric complications in deriving any inference from the empirical model. Given extensive financial deregulation and innovations introduced in the 1980s and 1990s, parameter constancy is pivotal in modelling money demand in NZ. 
Table 6:

Empirical results for the short-run demand for M3R model, $\Delta(\mathrm{m}-\mathrm{p})_{\mathrm{t}}$

\begin{tabular}{lcccc}
\hline \multicolumn{1}{c}{ Variable } & $\begin{array}{c}\text { Estimated } \\
\text { coefficients }\end{array}$ & $t$-statistics & Prob. & $\begin{array}{c}\text { Expected } \\
\text { signs }\end{array}$ \\
\hline Constant & 0.013 & 7.7 & {$[0.00]$} & \\
$\Delta y_{t}$ & 0.274 & 3.2 & {$[0.00]$} & + \\
$\Delta(R L-R S)_{t}$ & -0.717 & -2.4 & {$[0.02]$} & - \\
$\Delta(R L-R S)_{t-1}$ & 0.704 & 3.5 & {$[0.00]$} & $-/+$ \\
$\Delta e r_{t-1}$ & 0.218 & 2.9 & {$[0.01]$} & $-/+$ \\
$\Delta \pi_{t}^{e}$ & -0.368 & -2.1 & {$[0.04]$} & - \\
$\Delta \pi_{t-1}^{e}$ & 0.704 & 3.3 & {$[0.00]$} & $+/-$ \\
$\Delta(\mathrm{m}-\mathrm{p})_{\mathrm{t}-1}$ & -0.205 & -2.6 & {$[0.01]$} & $+/-$ \\
$e c_{t-1}$ & -0.315 & -5.8 & {$[0.00]$} & - \\
\hline
\end{tabular}

Order of integration of stochastic residuals: I( $(0)$

$R^{2}=0.50$ when solved for $\Delta(m-p)_{t} \quad F(8,43)=5.2 \quad[0.00]$

$R^{2}=0.998$ when solved for $(m-p)_{t}$

Diagnostic tests:

$D W$ 2.05

AR 1-4:

$F(4,39)=0.10$

ARCH 1-4

$F(4,35)=0.40$

[0.81]

Normality

$\chi^{2}(2)=1.14$

[0.57]

White heteroskedasticity:

$F(16,26)=0.60$

$[0.86]$

RESET

$F(1,42)=3.7$

[0.07]

* indicates that the standard errors of coefficients have been corrected by the White Heteroskedasticity-Consistent Standard Errors \& Covariance before calculating $t$-ratios.

Therefore, the estimated short-run model has been evaluated by a number of recursive stability tests displayed in Figure 2 in the following order:

$\left[\begin{array}{llll}a & b & c & d \\ e & f & g & h \\ i & j & k & l \\ m & n & & \end{array}\right]$

where panel (a) displays the recursive residuals; panel (b) depicts the CUSUM test; panel (c) illustrates the CUSUM of squares; panel (d) shows the recursive residuals and the corresponding one-step probability; panel (e) plots the recursive residuals and the corresponding n-step probability; and panels (f) to (n) reveal the recursively estimated 9 coefficients over the period 1991:3-2002:1 in the same order that these coefficients appear in Table 6 (from top to bottom). These evaluative tests are useful in assessing stability of a model, as recursive algorithms avoid arbitrary splitting of the sample. In 
addition to the graphical tests, the two versions of Chow tests (the forecast test and the breakpoint test) have been reported below Figure 2. Overall, the graphical tests and the Chow tests for stability reveal that aside from a minor and insignificant outlier around 1996, the test results point to the in-sample constancy of the estimated equation. In particular, the recursively estimated coefficients have remained relatively stable since 1997 when the RBNZ published its the Monetary Condition Index.

\section{Conclusion}

The formulation of a sound monetary policy presupposes a theoretically coherent and empirically robust model of money demand. A stable money demand function is essential for the effective conduct of monetary policy in offsetting the fluctuation that can emanate from the real sector of the economy. After briefly reviewing the literature on the demand for money, this paper examines the long- and short-run determinants of the demand for M3, which should be considered as one of the key indicators of monetary policy in NZ.

The ADF and KPSS tests for unit roots indicate that all the variables appearing on a standard money demand function are $\mathrm{I}(1)$. Thus, the Johansen multivariate cointegration test has been employed to determine the number of the cointegrating vector(s). Cointegration tests clearly indicate that there is a unique cointegrating vector, which links the real demand for M3R with real income, the interest rate spread (i.e. the 90-day/10-year yield gap or $R L-R S)$, the expected rate of inflation $\left(\pi^{e}\right)$, and the real effective (TWI) exchange rate (er). The VEC model in the cointegration test also included the US long-run interest rate $(F R)$ as a totally exogenous variable to the VAR system. Following the literature on the demand for money discussed earlier, a conventional demand for money model has been appropriately augmented in this paper 
by $F R$ and $e r$, supporting the currency substitution and capital mobility hypotheses in NZ as a small open country.

The estimated long-run income elasticity is significantly different from unity (1.47) which is not consistent with the quantity theory of money but it is in accord with earlier studies in the context of NZ. The long-run semi-elasticities of the interest rate spread, inflation, and the real effective (TWI) exchange rate with respect to real balances are $-4.03,-4.08$ and -0.208 , respectively. The estimated error correction term indicates that the selected interest rates adequately represent the prevailing interest rate regime in the economy.

The results, inter alia, indicate that both in the long- and short-run an increase in the expected inflation rate or a depreciation of the domestic currency can encourage agents to diversify their portfolios in the economy by acquiring real assets and/or foreign currencies in stead of holding M3R. This paper supports the view that M3R is a predictable monetary aggregate as long as it is well-specified. Therefore, one cannot justify the total abandonment of monetary aggregates solely on the basis of an observed instability in the money demand function. As seen from the literature sited in Section 2, in fact this instability in many countries has been attributable to the misspecification of the demand for money function, e.g. the exclusion of the relevant variables such as er, $F R$ and $R L$. The model developed in this paper can provide a useful policy guide for the RBNZ in its quest for price stability by measuring the long-run impact of key macroeconomic variables on money demand. The results obtained in this study are consistent with the view that the RBNZ should closely monitor the exchange rate and the interest rate spread as two important indicators of monetary policy because these two variables together with inflation expectations are major drivers of the demand for money both in the short- and long-run. 


\section{References}

Archer, D., Brookes, A, and Reddell, M. (1999), "A Cash Rate System for Implementing Monetary Policy", Reserve Bank of New Zealand Bulletin, Vol 62, No.1.

Australian Bureau of Statistics (2002), OECD, ABS, Canberra.

Bahmani-Oskooee, M. and Rhee, H.J. (1994), "Long-Run Elasticities of the Demand for Money in Korea: Evidence from Cointegration Analysis", International Economic Journal, 8(2), 83-93.

Ball, L. (2001), “Another Look at Long-Run Money Demand”, Journal of Monetary Economics, 47(1), 31-44.

Beyer, A. (1998), "Modelling Money Demand in Germany", Journal of Applied Econometrics, 13(1), 57-76.

Chowdhury, A.R. (1995), "The Demand for Money in a Small Open Economy: The Case of Switzerland", Open Economies Review, 6(2), 131-44.

Coenen, G. and Vega, J.L. (2001), “The Demand for M3 in the Euro Area”, Journal of Applied Econometrics, 16(6), 727-48.

de Brouwer, G., Ng, I., and Subbaraman, R. (1993), "The Demand for Money in Australia: New Tests on an Old Topic", Research Discussion Paper, No. 9314, Reserve Bank of Australia, Sydney.

Ericsson, N.R. (1998), "Empirical Modeling of Money Demand", Empirical Economics, 23(3), 295-315.

Ewing, B.T, and ; Payne, J.E. (1999), "Some Recent International Evidence on the Demand for Money", Studies in Economics and Finance, 19(2), 84-107.

Felmingham, B. and Zhang, Q. (2001) "The Long Run Demand for Broad Money in Australia Subject to Regime Shifts", Australian Economic Papers, 40(2), 146-55.

Giles DEA (1998), "Measuring the Hidden Economy: Implications for Econometric Modelling", Econometrics Working Paper EWP9809, Department of Economics, University of Victoria.

Hayo, B. (1999), "Estimating a European Money Demand Function”, Scottish Journal of Political Economy, 46(3), 221-44.

Hoffman, D.L. and Rasche, RH. (2001), Aggregate Money Demand Functions, Kluwer Academic Publishers, Boston.

Huxford, J. and Reddell, M. (1996), "Implementing Monetary Policy in New Zealand", Reserve Bank of New Zealand Bulletin, Vol 59, No.4. 
Johansen, S. (1991), "Estimation and Hypothesis Testing of Cointegration Vectors in Gaussian Vector Autoregressive Models”, Econometrica, 59(6), 1551-80.

Johansen, S. (1995), Likelihood-based inference in cointegrated vector autoregressive models, Oxford University Press, Oxford, New York.

Juselius, K. (1991), "Long-Run Relations in Australian Monetary Data", Department of Economics Working Paper No. 238, Australian National University, Canberra.

Juselius, K. and Hargreaves, C. P. (1992), "Long-Run Relations in Australian Monetary Data: Chapter 10 in Hargreaves, C.P. (ed), Macroeconomic Modelling in the Long Run, Edward Elgar, Aldershot, 249-85.

Laidler, D. (1991), "The Quantity Theory Is Always and Everywhere ControversialWhy?", Economic Record, 67(199), 289-306.

Laidler, D.E.W (1993), The Demand for Money: Theories, Evidence, and Problems, HarperColins College, New York.

Mundell, A. R. (1963), "Capital Mobility and Stabilisation Policy Under Fixed and Flexible Exchange Rates”, Canadian Journal of Economics and Political Science, 27, 475-85.

Orden, D. and Fisher,L.A. (1993), "Financial Deregulation and the Dynamics of Money, Prices, and Output in New Zealand and Australia”, Journal of Money, Credit, and Banking, 25(2), 273-92.

Razzak, W.A. (2001), "Money in the Era of Inflation Targeting", Reserve of New Zealand Discussion Paper No DP2001/02, Wellington.

Reserve Bank of New Zealand, 1998), The Impact of Monetary Policy on the Economy", Reserve Bank of New Zealand, Wellington.

Siklos, P.L. (1995a), “The Demand for Money in New Zealand in a Era of Institutional Change: Evidence from the 1981-1994 period”, New Zealand Economic Papers, 29(1), 21-40.

Siklos, P.L. (1995b), "Long-Run and Short-Run Money Demand: Which Price Deflator to Use? Some Evidence Using New Zealand Data", Applied Economics Letters, 2(6), 199-202.

Siklos, P.L. and Eckhold, K.R. (1997), "Income Velocity in Turbulent Times: The Role of Institutional Factors in the New Zealand Experience", Journal of Macroeconomics, 19(1), 31-52.

Svensson, L.E.O. (2001), Independent Review of the Operation of Monetary Policy, The Treasury, Wellington.

Traa, B.M. (1991), "Money Demand in the Netherlands", International Monetary Fund Working Paper, No. WP/91/57, IMF, Washington DC. 
Data Appendix: 1988:1-2002:2

\begin{tabular}{|c|c|c|c|c|c|c|c|c|}
\hline Obs. & M3R & $\mathrm{P}$ & M3R/P & ER & $\mathrm{RL}$ & $\mathrm{RS}$ & RL-RS & $\Delta_{4} \ln (P)$ \\
\hline 1988:01:00 & 38280 & 0.794 & 48218 & 66.3 & 0.136 & 0.166 & -0.030 & 0.086 \\
\hline 1988:02:00 & 38040 & 0.800 & 47544 & 66.6 & 0.129 & 0.160 & -0.031 & 0.062 \\
\hline 1988:03:00 & 38428 & 0.807 & 47606 & 64.4 & 0.127 & 0.146 & -0.019 & 0.055 \\
\hline 1988:04:00 & 38703 & 0.817 & 47384 & 60.6 & 0.133 & 0.144 & -0.011 & 0.046 \\
\hline 1989:01:00 & 39443 & 0.826 & 47764 & 59.8 & 0.132 & 0.135 & -0.003 & 0.039 \\
\hline 1989:02:00 & 40052 & 0.836 & 47932 & 61.0 & 0.132 & 0.134 & -0.002 & 0.043 \\
\hline 1989:03:00 & 41508 & 0.865 & 47987 & 60.9 & 0.125 & 0.133 & -0.008 & 0.069 \\
\hline 1989:04:00 & 41725 & 0.876 & 47653 & 60.8 & 0.124 & 0.140 & -0.016 & 0.070 \\
\hline 1990:01:00 & 41729 & 0.884 & 47215 & 61.6 & 0.122 & 0.138 & -0.016 & 0.068 \\
\hline 1990:02:00 & 42800 & 0.899 & 47593 & 60.8 & 0.123 & 0.136 & -0.013 & 0.073 \\
\hline 1990:03:00 & 43244 & 0.908 & 47610 & 60.8 & 0.126 & 0.143 & -0.017 & 0.049 \\
\hline 1990:04:00 & 45130 & 0.918 & 49156 & 59.0 & 0.128 & 0.138 & -0.011 & 0.047 \\
\hline 1991:01:00 & 45427 & 0.924 & 49174 & 58.8 & 0.116 & 0.121 & -0.005 & 0.044 \\
\hline 1991:02:00 & 46246 & 0.925 & 50017 & 59.4 & 0.102 & 0.105 & -0.003 & 0.028 \\
\hline 1991:03:00 & 46556 & 0.928 & 50174 & 57.9 & 0.097 & 0.093 & 0.004 & 0.021 \\
\hline 1991:04:00 & 47155 & 0.927 & 50863 & 55.2 & 0.089 & 0.080 & 0.009 & 0.010 \\
\hline 1992:01:00 & 49001 & 0.931 & 52627 & 54.2 & 0.091 & 0.074 & 0.017 & 0.008 \\
\hline 1992:02:00 & 49737 & 0.934 & 53274 & 53.7 & 0.088 & 0.069 & 0.019 & 0.010 \\
\hline 1992:03:00 & 49915 & 0.937 & 53277 & 53.5 & 0.079 & 0.062 & 0.017 & 0.010 \\
\hline 1992:04:00 & 50561 & 0.939 & 53828 & 53.6 & 0.078 & 0.064 & 0.013 & 0.013 \\
\hline 1993:01:00 & 50077 & 0.940 & 53268 & 53.6 & 0.077 & 0.075 & 0.002 & 0.010 \\
\hline 1993:02:00 & 52061 & 0.946 & 55044 & 54.1 & 0.073 & 0.067 & 0.006 & 0.013 \\
\hline 1993:03:00 & 53937 & 0.951 & 56734 & 55.4 & 0.066 & 0.055 & 0.011 & 0.015 \\
\hline 1993:04:00 & 54542 & 0.952 & 57268 & 56.0 & 0.061 & 0.056 & 0.006 & 0.014 \\
\hline 1994:01:00 & 54533 & 0.952 & 57258 & 56.7 & 0.059 & 0.049 & 0.010 & 0.013 \\
\hline 1994:02:00 & 56291 & 0.956 & 58870 & 56.6 & 0.072 & 0.062 & 0.011 & 0.011 \\
\hline 1994:03:00 & 56611 & 0.968 & 58507 & 57.2 & 0.085 & 0.072 & 0.012 & 0.018 \\
\hline 1994:04:00 & 57978 & 0.979 & 59222 & 58.5 & 0.089 & 0.087 & 0.003 & 0.028 \\
\hline 1995:01:00 & 60001 & 0.991 & 60576 & 59.8 & 0.085 & 0.094 & -0.008 & 0.039 \\
\hline
\end{tabular}

Source: Table 1. 
Data Appendix : 1988:1-2002:2 (Continued)

\begin{tabular}{|c|c|c|c|c|c|c|c|c|}
\hline Obs. & M3R & $P$ & M3R/P & ER & $\mathrm{RL}$ & $\mathrm{RS}$ & RL-RS & $\Delta_{4} \ln (P)$ \\
\hline 1995:02:00 & 61944 & 1.000 & 61944 & 60.8 & 0.076 & 0.091 & -0.015 & 0.045 \\
\hline 1995:03:00 & 62912 & 1.002 & 62793 & 61.7 & 0.078 & 0.090 & -0.012 & 0.035 \\
\hline 1995:04:00 & 65202 & 1.008 & 64710 & 61.9 & 0.072 & 0.085 & -0.013 & 0.029 \\
\hline 1996:01:00 & 66173 & 1.012 & 65363 & 64.3 & 0.074 & 0.087 & -0.013 & 0.022 \\
\hline 1996:02:00 & 70362 & 1.020 & 68982 & 64.6 & 0.085 & 0.097 & -0.012 & 0.020 \\
\hline 1996:03:00 & 71070 & 1.026 & 69289 & 65.7 & 0.084 & 0.100 & -0.016 & 0.023 \\
\hline 1996:04:00 & 73537 & 1.033 & 71167 & 67.1 & 0.073 & 0.089 & -0.016 & 0.025 \\
\hline 1997:01:00 & 73073 & 1.031 & 70910 & 68.4 & 0.075 & 0.076 & -0.001 & 0.018 \\
\hline 1997:02:00 & 74814 & 1.031 & 72537 & 67.9 & 0.076 & 0.072 & 0.004 & 0.011 \\
\hline 1997:03:00 & 76047 & 1.036 & 73391 & 64.8 & 0.069 & 0.081 & -0.011 & 0.010 \\
\hline 1997:04:00 & 77309 & 1.042 & 74200 & 63.9 & 0.068 & 0.079 & -0.011 & 0.008 \\
\hline 1998:01:00 & 78477 & 1.044 & 75184 & 61.2 & 0.068 & 0.090 & -0.022 & 0.013 \\
\hline 1998:02:00 & 78987 & 1.049 & 75326 & 58.5 & 0.067 & 0.091 & -0.024 & 0.017 \\
\hline 1998:03:00 & 78179 & 1.054 & 74152 & 57.1 & 0.062 & 0.068 & -0.006 & 0.017 \\
\hline 1998:04:00 & 79045 & 1.046 & 75591 & 56.0 & 0.055 & 0.046 & 0.009 & 0.004 \\
\hline 1999:01:00 & 80541 & 1.043 & 77228 & 57.6 & 0.056 & 0.045 & 0.012 & -0.001 \\
\hline 1999:02:00 & 79785 & 1.045 & 76364 & 59.1 & 0.061 & 0.047 & 0.014 & -0.004 \\
\hline 1999:03:00 & 82489 & 1.049 & 78644 & 56.7 & 0.068 & 0.048 & 0.020 & -0.005 \\
\hline 1999:04:00 & 82620 & 1.051 & 78611 & 54.4 & 0.071 & 0.054 & 0.017 & 0.005 \\
\hline 2000:01:00 & 82532 & 1.058 & 77985 & 54.1 & 0.073 & 0.060 & 0.013 & 0.015 \\
\hline 2000:02:00 & 83667 & 1.066 & 78509 & 53.5 & 0.069 & 0.067 & 0.002 & 0.020 \\
\hline 2000:03:00 & 83893 & 1.080 & 77657 & 50.2 & 0.067 & 0.067 & 0.000 & 0.029 \\
\hline 2000:04:00 & 84524 & 1.093 & 77346 & 47.8 & 0.065 & 0.067 & -0.002 & 0.039 \\
\hline 2001:01:00 & 84897 & 1.091 & 77837 & 50.5 & 0.060 & 0.064 & -0.004 & 0.030 \\
\hline 2001:02:00 & 87826 & 1.100 & 79834 & 49.7 & 0.065 & 0.059 & 0.006 & 0.032 \\
\hline 2001:03:00 & 90188 & 1.106 & 81515 & 50.0 & 0.066 & 0.057 & 0.009 & 0.024 \\
\hline 2001:04:00 & 91434 & 1.113 & 82173 & 49.6 & 0.064 & 0.050 & 0.014 & 0.018 \\
\hline 2002:01:00 & 93270 & 1.119 & 83359 & 51.6 & 0.067 & 0.050 & 0.017 & 0.026 \\
\hline 2002:02:00 & 95244 & 1.130 & 84257 & 54.6 & 0.068 & 0.058 & 0.009 & 0.027 \\
\hline
\end{tabular}

Source: Table 1. 
Figure 1. Plot of Time Series Data Employed (1988:2-2002:2)

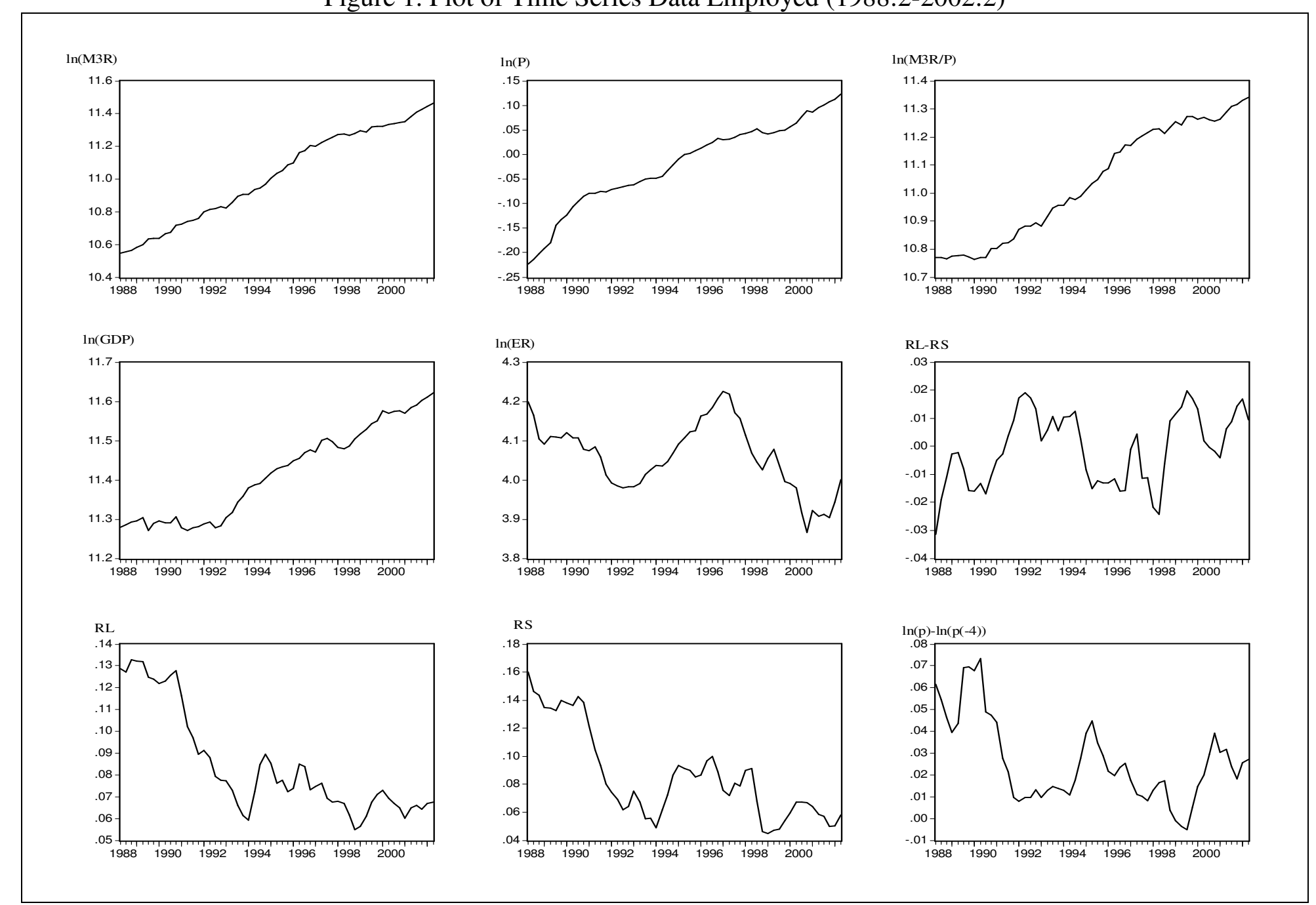

Source: Table 1. 
Figure 2. Graphical Tests for Stability of the Demand for Money Equation

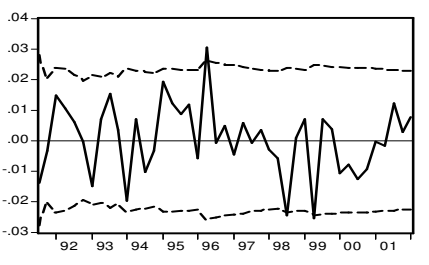

— Recursive Residuals -- \pm 2 S.I
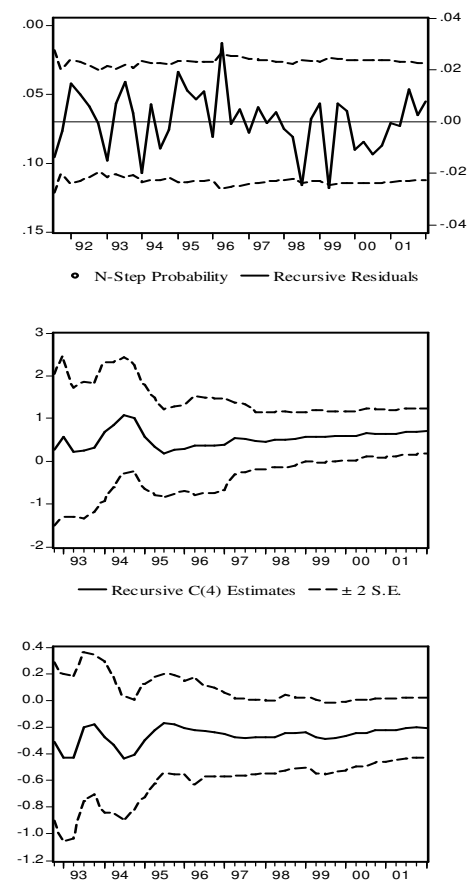

-

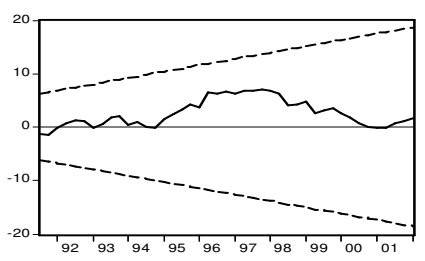

- Cusum $--5 \%$ Significance

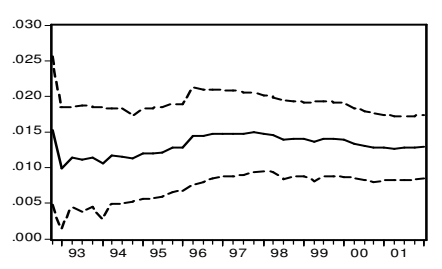

- Recurive $\mathrm{C}(1)$ Estinges - - 2 S S

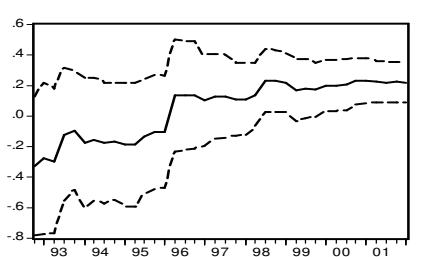

-- \pm 2 S.E

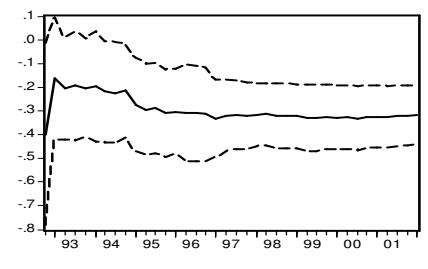

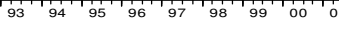

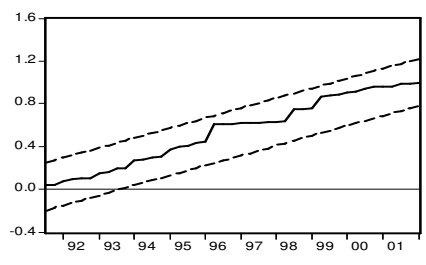

\begin{tabular}{llllllllll}
92 & 93 & 94 & 95 & 96 & 97 & 98 & 99 & & \\
\hline
\end{tabular}

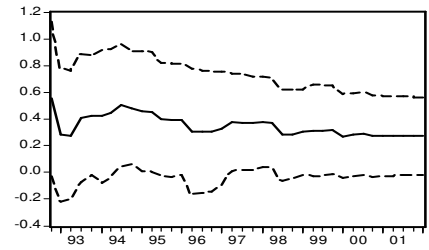

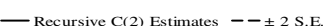

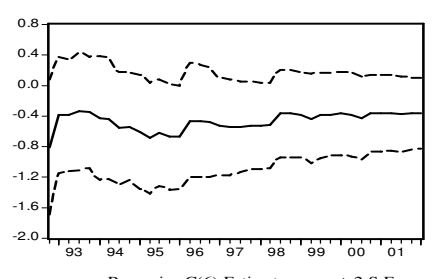

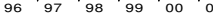

- Recursive C(6) Estimates - $\pm 2 \mathrm{~S}$.
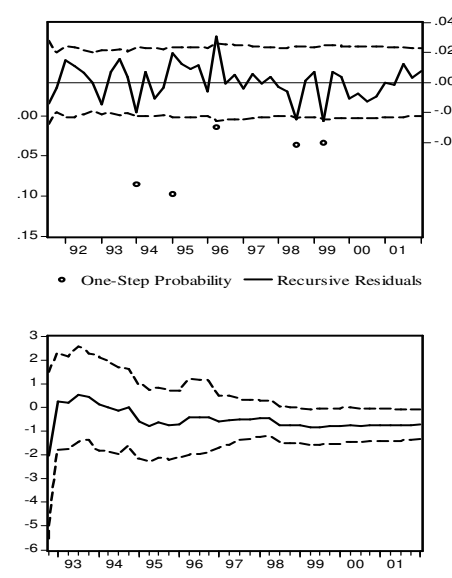

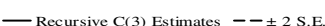

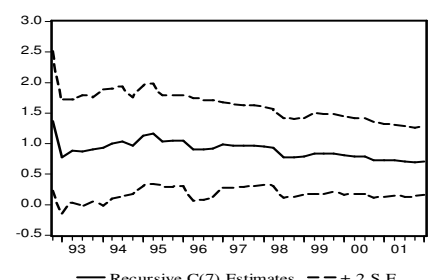

— Recursive C(7) Estimates - - 2 S S E

Chow tests: 1) Forecast test (2000:1-2002:1): $\mathrm{F}=0.50$ [prob.=0.86]; 2) Breakpoint test (1995:1) F=1.38 [prob.0.23]. 